\title{
PEPTIDE F (PRO-ENKEPHALIN FRAGMENT): RADIOIMMUNOASSAY, AND STRESS-INDUCED CHANGES IN ADRENAL
}

\author{
N. Alessi, L. Taylor*, and H. Akil
}

Mental Health Research Institute

University of Michigan

Ann Arbor, Michigan 48109

*Lafayette $\mathrm{Cl}$ inic

Detroit, Michigan

(Received in final form June 14, 1982)

\section{Summary}

Utilizing a nine amino-acid (Asp-Glu-LeuTyr-Pro-Leu-Glu-Val-Glu) non-enkephal in containing fragment of Peptide $F$ from the pro-enkephalin molecule, a radioimmunoassay was developed. Extraction of bovine, rat, and guinea pig adrenonedullary preparations demonstrated this fragment to be present and apparently partially conserved across species. In rats, acute inescapable foot-shock stress led to a significant decrease of the immunoreactive material in the adrenal medulla. Chronic daily stress for two weeks resulted in an inability of the adrenals to alter $F$ levels upon subsequent stress. The existence of F-like inmunoreactivity and its alteration by environmental manipulation, suggest that it may play a unique physiological role.

A number of findings have led to the rapid isolation and final sequencing of pro-enkephalin in the adrenal medulla $(1,2,3)$. Initially, these findings included the discovery of the presence of enkephal in-like immunoreactivity in the adrenal gland $(4,5)$, and later the isolation of the immunoreactivity to the adrenomedullary chromaffin granules $(5,6)$. Further work revealed a number of enkephalin containing fragments in chromaffin granules characterized by the presence of more than one copy of a biologically active peptile per fragment and their stability after enzymatic degralation (7). Peptide F, a thirty-four amino acid fragment (molecular weight 3840 daltons), was one of the initial sequences of the adrenal medulla pro-enkephalin molecule to be isolated and sequenced.

The question of whether the non-enkephalin portion of the enkephalin precursor possesses any biological function is of importance. The enkephalins are flanked with dibasic residues suggesting trypsin-like cleavages and the possibility of producing novel peptides which could be stored and co-released 
with the enkephalins. We therefore developed a radioimmunoassay for the midportion of the $F$ peptide. We have examined the regional distribution of $F$ in the rat brain. We have begun chromatographic studies to characterize the adrenal immunoreactivity. We have also studied physiological changes caused by a stress paradigm, which induces opioid-mediated stress analgesia ( 8 ).

The stress paradigm involves administration of acute footshock to the rat to produce naloxone reversible analgesia. When shock is delivered chronically over a period of two weeks "tolerance" appears to develop such that further stress is no longer effective in altering pain. Studies have implicated the adrenal medulla in the opiate-like analgesia seen with the acute stress $(9,10)$.

\section{Methods}

Radioimmunoassay

Peptide $F$ fragment. The nine-amino acid sequence was chosen because it did not include the enkephalin structures, had no complex amino-acids and had a tyrosine for iodination. This peptide was synthesized via solid phase method, coupled via glutaraldehyde to thyroglobulin and injected into rabbits. A number of antisera were developed and tested for crossreactivity prior to their use in the radioimmunoassay. The assay was carried out in potassium phosphate buffer (150mM, pH8.2, $18 \mathrm{NaCl}, 38 \mathrm{BSA})$. After an $18 \mathrm{hr}$ incubation, the charcoal-dextran technique was used for separation of bound from free 125 I $F$ peptide.

\section{Tissue Preparation}

Bovine adrenals were obtained from a slaughterhouse and stored on ice (15 min after death). The adrenal medullas were dissected out and the chromaffin granules were prepared by a standard procedure with a single modification (12). After isolation the chromaffin granules were homogenized in a solution of $1 \mathrm{M}$ acetic acid, $1 \mathrm{mM} \mathrm{HCl}$ for 30 seconds.

Rat and guinea pig adrenal medullas, and rat brains were obtained immediately following the decapitation of the animals. The adrenal. medullas were dissected out and frozen on dry ice until the time of further processing. The adrenal medulla from each animal were then homogenized in an acid:acetone solution containing iodoacetamide, and phenylmethylsulfonylfluoride. After the completion of their extraction, tissue specimens were then lyophilized until dry. The rat brains were dissected at the time of decapitation, and sections or regions were processed in the acid:acetone solution ( $75 \mathrm{vol} / \mathrm{wt})$.

\section{Stress Experiment}

Twenty-eight adult male Sprague-Dawley rats were divided into four groups. One group served as non-shocked control. A second group received $30 \mathrm{~min}$ of intermittant footshock (5 $\mathrm{mA}, 1$ sec duration, once per $5 \mathrm{sec}$ ) immediately before sacrifice (acute group). A third group received the same treatment daily 
for 14 days prior to the day of sacrifice. No shock was administered on the last day (chronic group). A final group was identical to the chronic group except the animals were also shocked imnediately before decapitation (chronic-acute).

\section{Results}

The antiserum chosen showed no cross-reactivity with Met-enkephalin, Leu-enkephalin, ACTH (1-27), alpha-MSH, or Beta-endorphin in our radioimmunoassay. The IC 50 was 300 fmoles/ml over a number of successive assays. Chromatography of extracts of rat adrenal medulla on Biogel $\mathrm{P}-2$, with $2 \mathrm{~N}$ acetic acid gave a single peak of immunoreactive material. The peak corresponded to a molecular weight of less than 1500 .

Bovine adrenomedullary chromaffin granules, rat and guinea pig adrenal preparations demonstrated the presence of both Leu-enkephalin immunoreactivity and peptide $F$ fragment immunoreactivity.

The results from the stress experiment are shown in Table I. Our data was analyzed using 4 (conditions) $x 3$ (trials) repeated measures by Analysis of Variance (ANOVA). The results showed that a statistically significant effect was found from these conditions $(\mathrm{F} \mathrm{3,24}=4.76 ; \mathrm{p}$;.01). Post hoc analysis using Neuman Keuls indicated that the control group differed significantly from the acute stress group ( $\mathrm{P}<.05$ ). In addition, after chronic stress the quantity of Peptide $F$ immunoreactivity was reduced and failed to show a response to acute stress.

TABLE I

Effect of Stress on the Levels of Peptide F

Fragment Immunoreactivity in Adrenal Medullas

$\begin{array}{lc}\text { Stress Condition } & \begin{array}{c}\text { Peptide F Fragment IR } \\ \text { (Fmoles/ng wet weight) }\end{array} \\ \text { Control }(n=7) & 83.48 \pm 8.42 \\ \text { Acute stress }(n=7) & 35.86 \pm 6.34 \\ \text { Chronic Stress }(n=7) & 52.71 \pm 6.20 \\ \text { Chronic/Acute } \\ \quad \text { Stress }(n=7)\end{array}$

Values are means $\pm S E$.

\section{Discussion}

The present study demonstrates that an antiserum can be successfully developed which will allow the study of the pro-enkephalin fragments not only in adrenal medulla, but in 
brain. The peptide $F$ fragment appears to be partially conserved across species as denonstrater by its presence in bovine, guinea pig, and rat adrenal inedullas, as well as several regions of rat brain. The site of the material suggests that it is further processea beyona cleavage away from the enkephalin. The exact identity of the peptire(s) being measured is under further study. The stress experiment demonstrated that F-like material responds to enviromenta? manipulation. The initial dranatic loss after $30 \mathrm{~min}$ is consistent with release of the material froin the gland. The lack of further responsiveness to acute stress in the chronically treater animals is consistent with the loss of benavioral analgesia after repeatel stress. Taken together, these results suggest a posible physiological role of the F-like material.

\section{Acknowledgements}

This work was supporter by NIDA grant \#ROIDA02265 and by a fellowship to NA granted by the University of Michigan Department of Psychiatry.

\section{References}

1. U. GUBLER, P. SEEBURG, B.J. HOFEMAN,

S. JDENFRIEND, Nature 295 206-208 (1982)

L.P. GAGE and

2. M. NODA, Y. FURUTANI, H. TAKAHASHT, M. TOYOSATO, T. HIROSE, S. INAYAMA, S. NAKANISHI and S. NUMA, Nature 295 202-206 (1982)

3. M. COMB, P.H. SEEBURG, J. ADELMAN, L. EIDEN anA E. HERBERT, Nature $295663-666$ (1982)

4. M. SCHULTZBBERG, T. HOKFELT, J. LUNDBERG, L. TERENIUS and L. ELFRIN Acta Physiol. Scand 103 475-477 (1978)

5. O.H. VIVEROS, E.J. DILIBERTO, E. HAZON and K-J. CHANG, MOL. Pharnacol. 16 liol-1108 (1979)

6. R. IEWIS, S. STERN, J. ROSSIER, S. STEIN and S. JDENFRIEND, Biochem. and Biophys. Research Communications 89 822-329 (1979)

7. S. KIMURA, R. LEWIS, A. STERN, J. ROSSIER, S. STEIN and S. UDENFRIED, Proc. Natl. Acad. Sci. USA 77 1681-1685 (1980)

8. H. AKIL, J. MADDEN, R.L. PATRICK and J.D. BARCHAS, Opiates an Endogenous opioid Peptides, pp. 63-70, Amsterdam, North Holland Pub. Co. (1976)

9. J.W. LEWIS, J.T. CANNON and J.C. LIEBESKIND, Science 208 $623-625(1980)$

10. J.W. LEWIS, J.E. SHERMAN and J.C. LIEBESKIND, Journal of Neuroscience 1 358-363 (1981)

11. J.W. LEWIS, M.G. TORDUFF, J.E. SHERMAN and J.C. LIEBESKIND, Abstracts Society for veuroscience 7735 (1981)

12. A.D. SMITH and H. WINKLER, Biochem. J. 103 480-482 (1967) 